\title{
Potencjał autofagii indukowanej przez genisteinę w leczeniu chorób neurodegeneracyjnych
}

\section{STRESZCZENIE}

L eczenie chorób neurodegeneracyjnych, schorzeń charakteryzujących się postępującą utratą komórek nerwowych, stanowi ogromne wyzwanie współczesnej medycyny. Poszukiwanie leków na te choroby trwa w wielu laboratoriach na świecie. Do dnia dzisiejszego zaproponowano kilka strategii terapeutycznych, które nie wykazują jednak wystarczającej skuteczności albo są jeszcze na wczesnym etapie badań przedklinicznych. Jednym z najnowszych podejść do terapii jest przyspieszona degradacja agregatów białkowych, które stanowią przyczynę aż 70\% tych schorzeń. Procesem, który mógłby zostać wykorzystany w tym celu jest autofagia czyli lizosomalna degradacja makrocząsteczek która odpowiednio zaindukowana mogłaby doprowadzić do takiego efektu. Poszukiwania związku, który nie tylko aktywowałby autofagię ale był także bezpieczny $w$ długoterminowym stosowaniu oraz przekraczał barierę krew-mózg doprowadziły do badań nad jednym z flawonoidów, genisteiną, którego szczególnie duże stężenia można znaleźć w soi. Badania przeprowadzone nad tym flawonoidem wskazały jego niezwykłą skuteczność $w$ usuwaniu agregatów białkowych tworzonych przez $\beta$-amyloid i hiperfosforylowaną formę białka tau, a także zmutowaną huntingtynę. Co więcej, u zwierząt będących modelami tych chorób wskazano na całkowite zniesienie kognitywnych i motorycznych objawów. Z uwagi na wysokie bezpieczeństwo stosowania genisteiny oraz fakt, że przekracza ona bariere krew-mózg, izoflawon ten jest kandydatem na skuteczny lek w leczeniu nie tylko choroby Alzheimera i Huntingtona ale także innych chorób spowodowanych agregacją białek. W manuskrypcie przedstawiono najnowsze dane dotyczące badań nad zastosowaniem genisteiny w modelach chorób neurodegeneracyjnych ze szczególnym naciskiem na jej działanie zależne od procesu autofagii.

\section{CHOROBY NEURODEGENERACYJNE}

Chorobami neurodegeneracyjnymi nazywamy grupę wrodzonych i nabytych chorób układu nerwowego, które charakteryzują się postępującą utratą komórek nerwowych. Obniżenie wydajności funkcjonowania neuronów prowadzi początkowo do łagodnych objawów, problemów z koordynacją ruchów lub zapamiętywaniem nazw. $\mathrm{Z}$ czasem choroby te prowadzą jednak do utraty pamięci, zdolności samodzielnego poruszania się, jasnego myślenia lub ogólnego funkcjonowania w świecie. Ostatecznie wiele z tych chorób kończy się śmiercią. Dokładne objawy chorób neurodegeneracyjnych zależne są od mechanizmu postawania choroby i przede wszystkim od miejsca występowania procesu chorobowego w układzie nerwowym. Najpowszechniejszymi i najbardziej znanymi przykładami chorób neurodegeneracyjnych są: choroba Alzheimera (AD), choroba Parkinsona (PD), choroba Huntingtona (HD) oraz stwardnienie zanikowe boczne (ALS), z których każda najczęściej objawia się w wieku po 50. roku życia [1].

Przyczynami schorzeń neurodegeneracyjnych mogą być zarówno zaburzenia wrodzone jak i rozwijane $\mathrm{w}$ trakcie życia [1]. Wśród nich wyróżnia się najczęściej: (a) nagromadzenie agregatów białkowych upośledzających funkcjonowanie neuronów (około 70\% chorób neurodegeneracyjnych) [2], (b) stany zapalne tkanki nerwowej [3], (c) zaburzenia funkcji mitochondriów lub innych organelli komórkowych, mających wpływ na energetykę komórkową [4], (d) demielinizację, czyli utratę osłonki mielinowej neuronów [5] (Ryc. 1). Zaburzenia neurodegeneracyjne różnią się objawami oraz przyczynami, jednak wszystkie prowadzą do tego samego - apoptozy, czyli zaprogramowanej śmierci komórki, której według stanu obecnej wiedzy, nie da się już odwrócić [1].

Według "World Alzheimer Report 2016" na samą AD w 2016 roku cierpiało między 28,5 mln a 33,3 mln ludzi na świecie. Światowa Organizacja Zdrowia (World Health Organisation) podaje, że liczba ta wzrośnie do ponad $75 \mathrm{mln} \mathrm{w}$ 2030 roku i do ponad $135 \mathrm{mln}$ w 2050 roku. Gdyby wziąć pod uwagę pacjentów $\mathrm{z}$ innymi chorobami neurodegeneracyjnymi razem z AD, to liczba chorujących na świecie przekracza $50 \mathrm{mln}$. Według danych organizacji „Alzheimer Europe” z 2015 roku w Polsce liczba osób chorujących na AD mieściła się w granicach dr Karolina Pierzynowska ${ }^{\varpi}$ mgr Zuzanna Cyske, dr Lidia Gaffke, mgr Estera Rintz, mgr Jagoda Mantej, dr Magdalena Podlacha, mgr Karolina Wiśniewska, Magdalena Żabińska, Maja Sochocka,

Patryk Lorenc,

Patrycja Bielańska,

Izabela Giecewicz,

prof. dr hab. Grzegorz

Węgrzyn

Katedra Biologii Molekularnej, Wydział Biologii, Uniwersytet Gdański

https://doi.org/10.18388/pb.2021_380

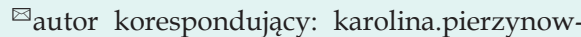
ska@ug.edu.pl

Słowa kluczowe: genisteina, flawonoidy, autofagia, choroby neurodegeneracyjne, strategie terapii

Wykaz skrótów: AD (ang. Alzheimer's disease) - choroba Alzheimera; ALS (ang. amyotrophic lateral sclerosis) - stwardnienie zanikowe boczne; ApoE - apoliproteina E; APP (ang. amyloid precursor protein) - prekursor $\beta$-amyloidu; HTT - huntingtyna; mHTT - zmutowana huntingtyna; PD (ang. Parkinson disease) - choroba Parkinsona; P-tau - hiperfosforylowana forma białka tau; SOD1 - dysmutaza ponadtlenkowa; mSOD - zmutowana dysmutaza ponadtlenkowa

Finansowanie: Powstała praca finansowana była przez Narodowe Centrum Nauki w ramach projektów nr: 2017/25/B/NZ2/00414, 2017/25/N/NZ2/00812, 2018/29/N/ NZ2/00802 i 2020/37/B/NZ2/01050. 

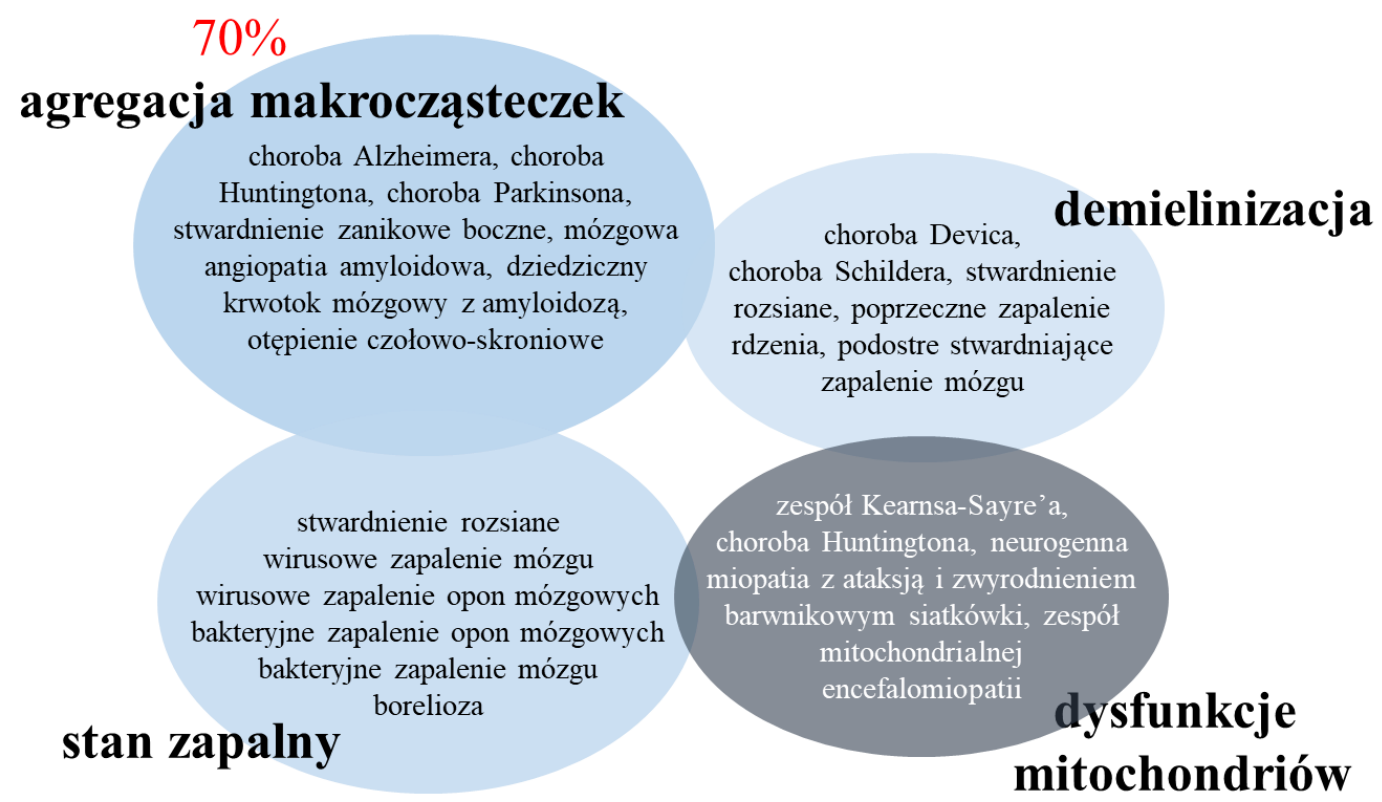

Rycina 1. Najczęściej wymieniane przyczyny chorób neurodegeneracyjnych wraz z przykładami.

360-470 tys. osób, co oznaczało liczbę o 20\% wyższą niż 10 lat wcześniej. Raport organizacji „Alzheimer's Disease International" zwraca uwagę na fakt, że choroby neurodegeneracyjne stanowią nie tylko duży problem medyczny dzisiejszego świata, ale prowadzą także do negatywnych skutków społecznych i ekonomicznych. Koszty związane z doraźnym leczeniem tych schorzeń, na które składają się zarówno koszty bezpośrednie (leków, hospitalizacji i opieki nad chorym) jak i pośrednie (utrata produktywności zawodowej nie tylko pacjenta ale i opiekuna) od 2015 roku przekraczają już 800 mld dolarów rocznie.

Poszukiwanie leków na te choroby jest wiec celem który staje się coraz pilniejszy. Złożone patomechanizmy tych schorzeń i wynikające z nich zróżnicowane objawy, które różnią się w zależności od choroby, środowiska i trybu życia pacjentów sprawiają, że poszukiwanie terapii dla tej puli chorób stanowi nie lada wyzwanie. Sytuacji nie pomaga fakt, że dojrzałe neurony nie ulegają regeneracji więc wszelkie uszkodzenia tych komórek wydają się niemożliwe do odwrócenia. Choroby neurodegeneracyjne, mimo dobrze rozwiniętej pomocy doraźnej dla pacjentów, pozostają nieuleczalne [6].

\section{STRATEGIE LECZENIA CHORÓB NEURODEGENERACYJNYCH}

Do dnia dzisiejszego opracowano wiele molekularnych strategii terapii chorób neurodegeneracyjnych. W dużej mierze zależą one od rodzaju konkretnego schorzenia, jego przyczyn oraz przebiegu. Niektóre strategie polegające na bardzo specyficznych mechanizmach działania potencjalnych leków mogą być stosowane w pojedynczych chorobach, inne uderzające $\mathrm{w}$ ogólne mechanizmy patogenezy stanowią szansę na terapię dla większej liczby opisywanych chorób [7].
Choroby neurodegeneracyjne charakteryzują się wieloma wspólnymi aspektami patogenezy. Są to między innymi stany zapalne czy wzrost poziomu reaktywnych form tlenu (ROS). Nie powinien dziwić więc fakt, że pierwsze terapie proponowane dla tych schorzeń obejmowały użycie środków antyoksydacyjnych czy łagodzących stan zapalny układu nerwowego. Wiele związków o działaniu przeciwzapalnym lub antyoksydacyjnym było testowanych $\mathrm{w}$ tym aspekcie (witamina E, minocyklina, erytropoetyna, rasagilina, ladostigil i inne). Niestety większość badań z ich udziałem nie wskazało na poprawę stanu pacjentów lub przez stosowanie $\mathrm{w}$ wysokich dawkach prowadziły one do wystąpienia poważnych efektów niepożądanych. $\mathrm{W}$ wielu $\mathrm{z}$ tych chorób obserwuje się także zaburzenia pozyskiwania energii i stąd strategia bazująca na poprawie funkcji mitochondriów. Wykorzystywany w tym celu dekspramipeksol nie wykazał skuteczności w próbie klinicznej, jednak wiele prób z innymi obiecującymi związkami o podobnym mechanizmie działania (TUDCA) dopiero się rozpoczyna [7].

Jednym z najstarszych podejść do łagodzenia objawów tych chorób jest także modulacja poziomu neuroprzekaźników, takich jak serotonina, dopamina lub glutaminian. W tym celu wykorzystuje się związki będące agonistami lub antagonistami dla receptorów tych neuroprzekaźników (przykładowo riluzol, lecozotan lub intepirdina, będące antagonistami odpowiednio, receptorów NMDA, 5-HT1A i 5-HT6). Ich użycie stosowane jest aktualnie $\mathrm{w}$ największej mierze u pacjentów jako leczenie wspomagające, jednak próby kliniczne $\mathrm{z}$ wykorzystaniem tych związków jako samodzielnych leków dla chorób neurologicznych nie przyniosły do tej pory spodziewanych efektów lub nie zostały zakończone [7]. Strategią cieszącą się popularnością, aczkolwiek będącą dopiero $\mathrm{w}$ trakcie badań na modelach zwierzęcych, stały się także próby poprawy żywotności neuronów poprzez blokowanie szlaków prowadzących do apoptozy $[8,9]$. 
Część zaproponowanych terapii obejmować może tylko wybrane choroby charakteryzujące się określonym aspektem patogenezy. Tak jest w przypadku użycia chelatorów jonów metali (żelaza, miedzi, wapnia i innych), które podejrzewa się o odgrywanie znaczącej roli zarówno w agregacji białek (a-synukleiny w PD oraz $\beta$-amyloidu w AD) jak i wytwarzaniu ROS. PBT-2, jeden $z$ antygrzybicznych związków będących chelatorem jonów metali, zastosowany w przypadku AD nie wykazał klinicznej skuteczności. Deferoksamina, będąca chelatorem jonów żelaza wykazała za to skuteczność w zahamowaniu neurodegeneracji spowodowanej pojawieniem się $\alpha$-synukleiny w PD w badaniach na modelu zwierzęcym, a deferypron (inny chelator żelaza) w badaniach klinicznych. Inne terapie ukierunkowane na zwalczenie mikroorganizmów próbuje się stosować jako leczenie wspomagające dla AD, w przypadku której zakażenia bakteryjne i wirusowe (m.in. Spirochetes, Helicobacter pylori, Chlamydophila pneumonia lub herpeswirusem) wydają się odgrywać znaczącą rolę w patogenezie tej choroby. Badania epidemiologiczne jasno wskazują, że leki antywirusowe na opryszczkę stosowane $u$ zakażonych tym wirusem ludzi zmniejszały ryzyko wystąpienia AD w przyszłości. Ponadto, badania wykonane $\mathrm{w}$ warunkach in vitro przyniosły dowody na zmniejszenie agregacji $\beta$-amyloidu i fosforylacji białka tau. Próby kliniczne z zastosowaniem leków antywirusowych przeciwko AD nie zostały rozpoczęte jednak są sugerowane przez środowisko naukowe [7].

Wiele z chorób neurodegeneracyjnych związanych jest z agregacją białek, dlatego też większość terapii celowanych jest w $\beta$-amyloid, hiperfosforylowaną formę białka tau (AD) a-synukleinę (PD), zmutowaną huntingtynę (HD) czy SOD (ALS). W największej mierze polegają one na hamowaniu transkrypcji genów kodujących te białka. Antysensowne oligonukleotydy czy krótkie interferujące cząsteczki RNA zastosowane zostały przykładowo w rodzinnych postaciach ALS ze zdiagnozowaną mutacją genu SOD1. Badania te przyniosły bardzo dobre wyniki na modelach zwierzęcych. Podobną strategię skierowaną przeciwko $\alpha$-synukleinie zastosowano $\mathrm{w}$ przypadku modeli zwierzęcych PD z podobnymi efektami. Innymi podejściami może być użycie specyficznych przeciwciał skierowanych przeciwko agregującym białkom. Użycie systemu biodegradowalnych nanocząsteczek w postaci pegylowanej do przeciwciał skierowanych bezpośrednio przeciwko $\beta$-amyloidowi wskazało na zmniejszenie agregatów tego białka w mózgowiu oraz częściowe przywrócenie pamięci w mysim modelu AD. W trakcie prób klinicznych II fazy znajduje się także wykorzystanie przeciwciał przeciwko agregatom a-synukleiny, które wydaje się przynosić pozytywne rezultaty w postaci obniżenia poziomu tego toksycznego białka w płynie mózgowo-rdzeniowym u pacjentów. Innymi terapiami skierowanymi przeciwko toksycznym formom białek zaproponowanymi do dnia dzisiejszego są zakłócanie tworzenia agregatów białkowych lub promowanie ich rozpadu. W strategiach tych przoduje wykorzystanie związków blokujących działanie kinaz fosforylujących białko tau (Tideglusib) oraz sekretaz prowadzących do powstawania krótkich, toksycznych odcinków $\beta$-amyloidu w AD (LY3202626 oraz Elenbecestat). Osobno terapie te nie wydawały się przynosić oczekiwanych rezultatów jednak ich kombinacje okazały się skuteczne w obniżaniu fosforylacji białka tau oraz agregacji $\beta$-amyloidu w badaniach przedklinicznych [7].

Ostatnią ze strategii, na którą kładzie się obecnie największy nacisk jest przyspieszona degradacja patogennych białek w komórkach. Strategia ta może obejmować aktywację dwóch szlaków: proteasomalnego, angażującego aparat proteasomu jako strukturę niezbędną do usunięcia agregatów białkowych lub procesu autofagii, który angażuje do tego celu system lizosomalny. Strategia ta jest o tyle ciekawa, że w odpowiednim nasileniu umożliwia selektywne usunięcie agregujących białek z komórek bez naruszenia ich natywnych form. Stosowano już wiele związków, które wydawały się być odpowiednimi kandydatami na leki w przypadku tej strategii terapeutycznej a przodują wśród nich induktory procesu autofagii [10].

\section{PROCES AUTOFAGII}

Autofagia jest filogenetycznie starym, konserwowanym ewolucyjnie procesem zachodzącym we wszystkich komórkach eukariotycznych. Wykryto ją zarówno u drożdży (Saccharomyces cerevisiae), muszki owocowej (Drosophila melanogaster), jak i w komórkach ssaczych [11]. Polega ona na lizosomalnej degradacji wielkocząsteczkowych składników cytoplazmy, szczególnie białek o długim okresie półtrwania, jak i całych organelli komórkowych [12]. Kiedy strawieniu ulega losowo wybrana część cytoplazmy z zawartymi w niej składnikami, autofagię określa się mianem nieselektywnej. Służy ona zachowaniu równowagi w wielkości i składzie cytoplazmy. Z autofagią selektywną ma się do czynienia, gdy degradowane zostają ściśle określone struktury np. mitochondria (mitofagia), retikulum endoplazmatyczne (retikulofagia) lub rybosomy (rybofagia) [13].

Autofagia pełni w komórce eukariotycznej wiele funkcji. W prawidłowo funkcjonującej komórce zachodzi na stałym poziomie podczas jej różnicowania, rozwoju lub przebudowy. Nazywana jest wtedy autofagią podstawową (konstytutywną). Umożliwia ona zachowanie homeostazy poprzez usuwanie uszkodzonych lub zbędnych organelli komórkowych lub poprzez regulację wielkości retikulum endoplazmatycznego [14]. Ponadto, utrzymuje równowagę pomiędzy syntezą a degradacją składników komórkowych. Bierze ona również udział $\mathrm{w}$ wielu procesach fizjologicznych, takich jak synteza neurolaminy w dopaminergicznych neuronach, biogeneza surfaktantu w pneumocytach, czy dojrzewanie erytrocytów [15]. Do nasilenia procesu autofagii może dochodzić również w skutek stresu komórkowego. Nazywana jest wtedy autofagią indukowaną. Czynnikami stresującymi, które stymulują autofagię mogą być: brak czynników wzrostu lub substancji odżywczych, pojawienie się ROS i źle sfałdowanych białek, infekcja wirusowa, czy uszkodzenia DNA. W takich przypadkach przyczynia się ona do adaptacji komórki do nowych, niekorzystnych warunków środowiskowych, ponieważ zapewnia stały dopływ składników odżywczych potrzebnych do utrzymania podstawowych funkcji życiowych komórki poprzez degradację mniej ważnych w danym momencie składników. Ponadto, chroni zainfekowaną komórkę przed namnażaniem się wirusów lub bakterii [16]. 
Wyróżnia się trzy podstawowe postacie procesu autofagii, które wyszczególniono na podstawie sposobu dostarczenia substratu do lizosomu: i) mikroautofagię, ii) makroautofagię oraz iii) autofagię zależną od białek opiekuńczych (chaperonów) [17]. Mikroautofagia jest najmniej poznanym rodzajem autofagii, w którym strawieniu ulegają małe organella komórkowe i związki rozproszone w cytoplazmie [18]. W takiej sytuacji fragment cytoplazmy ulega sekwestracji bezpośrednio przez lizosom, dzięki inwaginacji błony lizosomalnej [19]. Autofagia zależna od chaperonów charakteryzuje się wiązaniem pojedynczych białek lub peptydów mających ulec degradacji przez białka z rodziny Hsp70, tworzac kompleks chaperon-substrat. Kompleks ten dzięki obecności receptorów Lamp2a w błonie lizosomalnej transportowany jest do wnętrza lizosomu, gdzie ulega hydrolizie [20]. Warto zauważyć, że jedynym organellum niezbędnym do zajścia tych dwóch rodzajów autofagii jest lizosom.

Inaczej wygląda mechanizm degradacji makrocząsteczek w przypadku makroautofagii, w której do usunięcia struktur komórkowych potrzebna jest fuzja lizosomu z autofagosomem. Jest to najpowszechniej występująca postać autofagii. W początkowym etapie tego procesu fragment cytoplazmy wraz ze znajdującymi się w niej białkami o długim okresie półtrwania lub całymi organellami zostaje otoczony przez podwójną błonę izolującą nazywaną fagoforem. Struktura ta następnie zamyka się tworząc autofagosom, do którego dołączają się wczesne i późne endosomy. Dostarczają one czynników niezbędnych do fuzji z lizosomem i czynników obniżających $\mathrm{pH}$, aby stworzyć odpowiednie środowisko dla działania enzymów lizosomalnych. Autofagosom ulega następnie fuzji z lizosomem, co prowadzi do powstania autofagolizosomu. $\mathrm{W}$ tak powstałych strukturach zachodzi proces hydrolizy wewnętrznej błony autofagosomu oraz wielkocząsteczkowych białek i organelli do podstawowych związków chemicznych, takich jak aminokwasy, które następnie ponownie zużywane są przez komórkę [11,17,21].

Długotrwała i intensywna autofagia doprowadzić może komórkę do śmierci, zwanej programowaną śmiercią komórki typu II lub programowaną śmiercią komórki związaną z autofagią. Ten rodzaj śmierci komórkowej objawia się poprzez kondensację chromatyny i degradację głównych struktur komórkowych, takich jak siateczka śródplazmatyczna, aparat Golgiego, czy rybosomy. W odróżnieniu od programowanej śmierci komórki typu I (apoptozy), szlak prowadzący do śmierci w tym przypadku nie jest zależny od kaspaz, a obserwuje się w nim podwyższoną aktywność enzymów lizosomalnych [14]. Jednak nie tylko zwiększona aktywność, ale i zahamowanie autofagii może mieć szkodliwe skutki dla komórki. Udowodniono, że przewlekła inhibicja tego procesu prowadzi do powstawania nowotworów na skutek wad we wzroście komórek lub braku stabilności ich genomu [22].

\section{ZWIĄZKI INDUKUJĄCE AUTOFAGIĘ JAKO OBIECUJAॄCE TERAPEUTYKI DLA CHORÓB NEUROLOGICZNYCH}

Ponad 70\% chorób neurodegeneracyjnych związanych jest z agregacją nieprawidłowo sfałdowanych białek, które gromadząc się $\mathrm{w}$ neuronach powodują ich uszkodzenie $\mathrm{i}$ prowadzą do poważnych zaburzeń psychomotorycznych. Farmakologiczną indukcję autofagii uważa się za jedno z najbardziej obiecujących podejść do terapii dla takich chorób [10]. Alternatywny szlak degradacji białek, system ubikwityna-proteasom, jest znacznie mniej skuteczny w tym aspekcie $\mathrm{z}$ uwagi na poważne uszkodzenia proteasomu przez nowo formujące się agregaty białkowe w przypadku tych chorób [23]. Badania nad terapeutycznym zastosowaniem aktywatorów autofagii w chorobach neurodegeneracyjnych prowadzone są $\mathrm{w}$ wielu laboratoriach na całym świecie. Strategia farmakologicznej stymulacji degradacji toksycznych makrocząsteczek jest obecnie testowana z wykorzystaniem zarówno komórkowych, jak i zwierzęcych modeli chorób neurodegeneracyjnych, natomiast ze względu na stosunkowo niedawne rozpoczęcie takich badań istnieje zaledwie kilka zakończonych badań klinicznych, a większość $\mathrm{z}$ nich jest $\mathrm{w}$ toku lub na etapie rekrutacji pacjentów.

Opisane do dnia dzisiejszego związki naturalne będące induktorami autofagii, mogące mieć zastosowanie w leczeniu chorób neurodegeneracyjnych, podzielić można na trzy ogólne grupy: (a) polifenole; (b) alkaloidy i (c) izotiocyjaniany. Najczęściej występują one w roślinach leczniczych oraz różnego rodzaju warzywach i owocach. Należą do nich kurkumina, kwercetyna, resweratrol, sulforafan, berberyna, psammaplina, spermidyna, kampferol i wiele innych [24].

Chociaż istnieje wiele zachęcających wyników uzyskanych w eksperymentach na modelach komórkowych i zwierzęcych z udziałem wymienionych uprzednio induktorów autofagii, nie są jeszcze dostępne konkretne metody leczenia z ich udziałem. Związki te albo znajdują się jeszcze w fazach badań przedklinicznych albo okazują się nie przekraczać bariery krew-mózg co jest aspektem szczególnie istotnym $\mathrm{w}$ nawiązaniu do terapii chorób neurodegeneracyjnych. Jednym z najważniejszych problemów jest także występowanie poważnych skutków ubocznych podczas dłuższego testowania silnych stymulatorów autofagii. Jako, że stymulacja tego procesu jest też jedną ze strategii terapii antynowotworowej, warto wspomnieć, że stosowanie silnych stymulatorów autofagii przeciwko nowotworom może zadziałać pod warunkiem terapii krótkotrwałej (okres do kilku miesięcy). Natomiast pacjenci z chorobami neurodegeneracyjnymi musieliby prawdopodobnie taki lek przyjmować do końca życia, co znacząco ogranicza możliwości wyboru związku stymulującego autofagię z dużymi efektami niepożądanymi dla pacjentów. Takie efekty obserwowano dla rapamycyny, nimodypiny, loperamidu, niguldypiny, nikardypiny, panitremu A, fluspirylenu, kalpastatyny i karbamazepiny [10].

Z tych powodów nieustannie poszukuje się związków, które nie tylko stymulują degradację nagromadzonych, toksycznych makrocząsteczek, ale także przekraczają barierę krew-mózg oraz są bezpieczne i nadają się do długotrwałego stosowania bez poważnych skutków ubocznych.

\section{GENISTEINA}

Genisteina [5,7-dihydroksy-3-(4-hydroksyfenylo)-4H-1-benzopiran-4-on] to jeden $\mathrm{z}$ flawonoidów fitoestroge- 
nowych należących do grupy izoflawonów, wykazujących szerokie spektrum aktywności biologicznych [25]. Najwyższe jej stężenie znajduje się $\mathrm{w}$ roślinach strączkowych (Fabaceae), głównie w nasionach soi (Glycine max), fasoli (Phaseolus vulgaris), grochu (Pisum sativum), bobu (Vicia faba) czy kudzu (Pueraria lobata). Szacuje się, że genisteina stanowi aż ponad $50 \%$ zawartości wszystkich izoflawonów w produktach sojowych [25] (Ryc. 2).

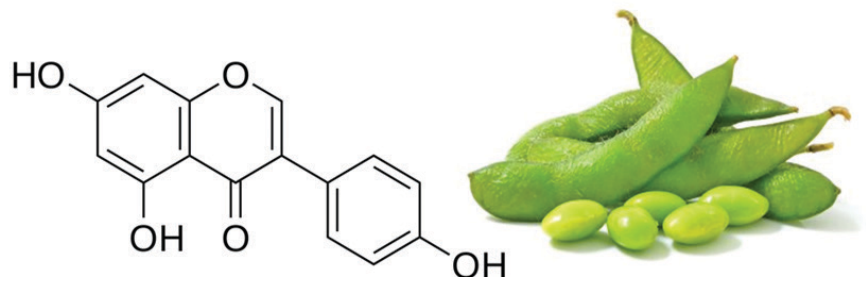

Rycina 2. Genisteina i jej podstawowe źródło.

Izoflawony są substancjami o wielu zastosowaniach. Między innymi chronią rośliny przed infekcjami bakteryjnymi i grzybiczymi oraz pełnią rolę fitoestrogenów o różnorodnym działaniu farmakologicznym w komórkach zwierzęcych [26]. Podobieństwo budowy chemicznej genisteiny do $17 \beta$-estradiolu sprawia, że naśladuje ona wiązanie estrogenów z odpowiednimi receptorami wywierając działanie estrogenne $w$ docelowych narządach, co jest przedmiotem badań opierających się na jej wykorzystaniu w różnych terapiach hormonalnych [27]. Cząsteczka ta wykazuje również zdolność do wywoływania wielu efektów molekularnych, które mogą zostać wykorzystane w celach terapeutycznych, jak np. hamowanie stanów zapalnych, promowanie apoptozy, modulację aktywności receptorów hormonów steroidowych i szlaków metabolicznych [28].

W związku z tym, że rośliny są stale narażane na promieniowanie UV, niektóre $\mathrm{z}$ ich metabolitów wtórnych $\mathrm{w}$ toku ewolucji nabyły cechy nadające oporność na mutagenne działania promieniowania ultrafioletowego. Taką właściwość radioprotekcyjną zaobserwowano między innymi w przypadku genisteiny. Jak wiadomo, ekspozycja na różnego rodzaju promieniowania generuje powstawanie wewnątrzkomórkowych ROS, co powoduje uszkodzenia DNA. Dzięki temu, że genisteina sprawnie inaktywuje wolne rodniki, a dodatkowo działa silnie przeciwutleniająco i przeciwzapalnie, osłabiając działanie cytokin prozapalnych, analizuje się jej wspierające zastosowanie $\mathrm{w}$ roli radioprotektora $\mathrm{w}$ warunkach klinicznych $[29,30]$. Ze względu na unikalną budowę i posiadanie fenolowej grupy hydroksylowej, przejawia ona także silne działanie przeciwutleniające w układach enzymatycznych. Działanie przeciwutleniające tej cząsteczki ułatwia komórce procesy naprawy powstałych uszkodzeń [31].

Genisteina wykazuje także działanie przeciwnowotworowe. Opiera się ono na zdolności do hamowania przez ten związek kinaz tyrozynowych co wpływa między innymi na inhibicję autofosforylacji receptora naskórkowego czynnika wzrostowego, EGFR (który ulega nadmiernej aktywacji w większości nowotworów) [32,33]. Ze względu na zdolność do indukcji apoptozy w komórkach nowotworowych przez genisteinę, istnieją obawy dotyczące jej wpływu na komórki nie dotknięte zmianami chorobowymi. Rzeczywiście, niektóre badania przeprowadzone na zwierzętach i ludziach wskazują na możliwe negatywne działanie fitoestrogenów, w tym genisteiny, na zdrowe komórki. Jednak okazuje się, że rezultat ten zależy od użytego stężenia substancji. Wykazano, że niekorzystne jej działanie pojawia się w przypadku wysokich dawek, które znacznie przekraczają dawki możliwe do osiągnięcia przy stosowaniu diety bogatej w genisteinę czy suplementy na niej oparte [32].

Oprócz wymienionych powyżej cech genisteiny, charakteryzuje się ona dodatkowymi aspektami działania, które stawiają ją jako bardzo dobrego kandydata na lek dla chorób neurodegeneracyjnych. Przede wszystkim, dane literaturowe wskazują na inaktywację kinazy mTOR w różnych rodzajach komórek (między innymi podocytach) pod jej wpływem, co jest sygnałem do zahamowania procesów syntezy białek oraz indukcji autofagii [34]. Ponadto, niezależnie od samego zahamowania aktywności kinazy mTOR, w wyniku działania genisteiny wskazano na podwyższenie poziomu ekspresji genów kodujących białka biorące udział $\mathrm{w}$ formowaniu autofagosomów i funkcji lizosomalnych poprzez regulację czynników transkrypcyjnych EB oraz FoxO3 $[35,36]$.

Genisteina, ze względu na niewielki rozmiar i specyficzną budowę cząsteczki, jest $\mathrm{w}$ stanie także pokonać barierę krew-mózg, dzięki czemu może być stosowana do leczenia chorób o ciężkich objawach neuropatycznych [37]. Uwagę zwraca też fakt bezpieczeństwa jej stosowania. Testowana była ona już w próbach klinicznych na dzieciach z mukopolisacharydozą w wysokich dawkach przez okres 2 lat, nie wykazując żadnych istotnych efektów niepożądanych [38].

\section{POTENCJAŁ GENISTEINY W LECZENIU CHOROBY ALZHEIMERA}

Choroba Alzheimera (AD) jest obecnie przyczyną 60-70\% demencji. Za główną jej przyczynę uważa się płytki amyloidowe złożone z krótkich odcinków $\beta$-amyloidu oraz splątki neurofibrylarne złożone $\mathrm{z}$ hiperfosforylowanej formy białka tau. $\mathrm{W}$ rodzinnych formach choroby (ang. familial AD; fAD) jest to związane $z$ mutacjami w genie kodującym prekursor $\beta$-amyloidu, APP lub $\mathrm{w}$ genach prenisilin, PSEN1 i PSEN2, które przecinają białko APP prowadząc do powstania $\beta$-amyloidu. Za genetyczny czynnik ryzyka AD uważa się także mutacje w genie APOE4 kodującym apoliproteinę odpowiedzialną za transport cholesterolu w obrębie układu nerwowego [10,39].

Badania nad wykorzystaniem genisteiny w leczeniu AD prowadzone były zarówno na modelach komórkowych jak i zwierzęcych i wiele właściwości tego izoflawonu zostało przetestowanych $\mathrm{w}$ takich badaniach.

\section{REDUKCJA NEUROTOKSYCZNOŚCI/HAMOWANIE APOPTOZY WYWOEANEJ POJAWIENIEM SIE TOKSYCZNYCH FORM $\beta$-AMYLOIDU I HIPERFOSFORYLOWANEGO BIAŁKA tau}

Jedną z właściwości genisteiny jest hamowanie szlaków prowadzących do śmierci komórkowej, w przypadku cho- 
rób neurodegeneracyjnych, neuronów. Badania takie prowadzone były najczęściej na modelach komórek odzwierciedlających komórki nerwowe, astrocytach lub neuronach (w badaniach in vitro) lub na modelach mysich i szczurzych. Badania te wskazały, że genisteina hamuje śmierć komórek wywołaną iniekcją krótkich odcinków $\beta$-amyloidu, najczęściej $\beta$-amyloidu(25-35) w komórkach PC12 [40-43], neuronach hipokampu [44-46] lub komórkach neuroblastomy SH-SY5Y [47-50]. W obserwowany efekt zaangażowanych może być wiele szlaków sygnalizacyjnych zależnych od kinazy JNK [42,43], kinazy białkowej C (ang. PKC) [41], kinazy Akt $[49,46]$, erytroidowego czynnika jądrowego 2 (NRF2) [50], a także od zmian właściwości elektrofizjologicznych kanałów jonowych [45]. Ponadto, w wielu z tych badań odnotowano obniżenie poziomu ekspresji genów kodujących kaspazy i zahamowanie ich aktywności, głównie kaspazy 3 i 8, pod wpływem tego flawonoidu $[42,44]$. Badania na modelu szczurzym dowiodły, że genisteina hamuje wewnętrzny szlak indukcji apoptozy poprzez negatywny wpływ na poziom kaspazy 3, białka Bax oraz cytochromu c u szczurów po domózgowym wstrzyknięciu $\beta$-amyloidu (25-35). Prowadzi to do obniżenia poziomu neurodegeneracji oraz poprawy pamięci i zdolności uczenia się [51].

\section{REDUKCJA STRESU OKSYDACYJNEGO I ZAHAMOWANIE STANU ZAPALNEGO WYWOŁANYCH POJAWIENIEM SIĘ TOKSYCZNYCH FORM $\beta$-AMYLOIDU I HIPERFOSFORYLOWANEGO BIAŁKA tau}

Nieodłączną częścią patogenezy AD jest wzrost poziomu ROS. Redukcję ich poziomu, a co za tym idzie uszkodzeń DNA spowodowanych ich pojawieniem się, zaobserwowano na modelu transgenicznym $C$. elegans z ekspresją ludzkiego $\beta$-amyloidu [52] lub na szczurzym modelu po iniekcji $\beta$-amyloidu(25-35) [53]. Badania wykonane na szczurzej linii komórek mikrogleju (HAPI) wskazały na zmniejszenie poziomu mRNA syntazy tlenku azotu, co skutkowało jego zmniejszoną produkcją indukowaną przez lipopolisacharyd [54]. Genisteina wykazała także efektywność w obniżaniu poziomu dialdehydu malonowego (MDA), którego podwyższony poziom zaobserwowano u szczurów po iniekcji $\beta$-amyloidu(1-40) do hipokampa, co prowadziło do poprawy zdolności kognitywnych zwierząt [55]. Warto także zwrócić uwagę na wpływ genisteiny na mitochondria jako organella generujące największe ilości ROS. Badania wykonane na modelu komórek glejaka C6 wskazały, że zarówno poziom ROS jak i uszkodzenia mitochondrialnego DNA wywołane przez $\beta$-amyloid zostały znacząco zmniejszone, a poziom enzymów antyoksydacyjnych zwiększony, po uprzedniej inkubacji komórek $\mathrm{w}$ obecności genisteiny [56].

Aktywacja stanu zapalnego jest kolejnym elementem towarzyszącym AD. Przeciwzapalne właściwości genisteiny mogły więc zostać wykorzystane jako kolejny mechanizm łagodzenia objawów choroby. Badania na komórkach mikrogleju BV-2 wykazały, że genisteina potrafi obniżyć cytotoksyczność oraz stan zapalny wywołany przez $\beta$-amyloid(25-35) poprzez obniżenie poziomu receptora TLR4 oraz czynnika jądrowego NF- $\mathrm{B}$, zaangażowanych $\mathrm{w}$ ten proces [57]. Innymi mediatorami stanu zapalnego, badanymi w kontekście aktywności przeciwzapalnych geniste-

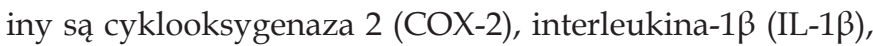
syntaza tlenku azotu (iNOS) lub czynnik martwicy nowotworów (TNF-a). Preinkubacja pierwotnych astrocytów w obecności genisteiny zapobiegała aktywacji tych czynników pod wpływem $\beta$-amyloidu [58]. Dodatkowo badania wykonane na modelu szczurzym wskazały, że genisteina chroni przed rozległą astrogliozą $\mathrm{w}$ hipokampie spowodowaną wstrzyknięciem $\beta$-amyloidu [59].

\section{MODULACJA POZIOMU NEUROTRANSMITERÓW I TRANSMISJI SYNAPTYCZNEJ W CHOROBIE ALZHEIMERA}

Zaburzenia transmisji synaptycznej już od dawna obserwowane są w chorobach neurologicznych, w tym w AD. Może odpowiadać za to między innymi deficyt acetylocholiny, jednego z neurotransmiterów. Związki hamujące aktywność enzymów rozkładających acetylocholinę czyli acetylocholinoesterazę lub butyrylocholinoesterazę są zatem kandydatami na leki poprawiające stan pacjentów. Badania wskazały, że genisteina jest jednym ze związków posiadających zdolności hamowania aktywności butyrylocholinoesterazy [60]. Ponadto, badania na modelu pierwotnych neuronów hipokampu szczurów wystawionych na działanie $\beta$-amyloidu(25-35) wskazały, że genisteina zwiększa efektywność ekspresji genu kodującego acetylotransferazę cholinową biorącą udział $\mathrm{w}$ syntezie acetylocholiny poprzez aktywację receptorów estrogenowych, co ma działanie neuroprotekcyjne [61].

Inne badanie, wykonane na modelu komórek SH-SY5Y wskazało, że preinkubacja $\mathrm{z}$ genisteiną chroni komórki przed indukowanym $\beta$-amyloidem obniżeniem poziomu czynników synaptycznych takich jak synaptofizyny i markera postsynaptycznego-95. Co więcej, genisteina zapobiegała zaburzeniom poziomu wewnątrzkomórkowego $\mathrm{Ca}^{2+}$ niezbędnego do prawidłowej transmisji sygnału [62]. Badania te potwierdzone zostały na modelu szczurzym po dokomorowej iniekcji $\beta$-amyloidu(1-42), w których genisteina poprzez zniesienie efektu obniżenia poziomu synaptycznych białek synaptofizyny i markera postsynaptycznego-95, prowadziła do poprawy parametrów poznawczych u zwierząt [63].

\section{TERAPIE SKIEROWANE PRZECIWKO POWSTAWANIU TOKSYCZNYCH FORM $\beta$-AMYLOIDU I HIPERFOSFORYLOWANEGO BIAŁKA tau}

Jako, że $\beta$-amyloid oraz hiperfosforylowaną formę białka tau uważa się za podstawowe przyczyny AD, nie powinien dziwić fakt, że to właśnie one stanowią cel wielu strategii terapii. Jedna $\mathrm{z}$ nich opiera się na obniżeniu poziomu bądź aktywności białek przecinających prekursor $\beta$-amyloidu, APP, do jego krótkich toksycznych form. Wiele badan nad genisteiną wskazuje na jej aktywność w obniżaniu poziomu lub aktywności sekretaz [64,65], prenisilin [66,67], czynnika wzrostu pochodzenia płytkowego (PDGF) [68] a także rakowego inhibitora fosfatazy białkowej 2A (CIP2A) [69] lub zwiększaniu poziomu apoliproteiny [70] co ostatecznie prowadzi do obniżenia poziomu toksycznego $\beta$-amyloidu. Natomiast strategia skierowana przeciwko fosforylacji białka tau wykorzystuje zdolności genisteiny do wiązania się do receptora estrogenowego co w konsekwencji poprzez modulację wewnątrzkomórkowego poziomu wapnia wpływa 
na zahamowanie aktywności zależnej od wapnia/kalmoduliny kinazy białkowej (CAMK4) oraz całej kaskady kinaz fosforylujących tau [71].

Szczególnie ciekawe badania nad wpływem genisteiny na poziomy $\beta$-amyloidu wykonane zostały na myszach, którym $\beta$-amyloid podawano do ścian przewodu pokarmowego. Wyniki tych badań wskazały, że fluorescencyjnie znakowany $\beta$-amyloid wstrzyknięty do żołądka może gromadzić się w warstwie neuronów mięśniowo-jelitowych i migrować do jelita czczego lub przez nerw błędny do mózgu prowadząc do zaburzeń kognitywnych. Flawonoidy, w tym genisteina, zapobiegały temu zjawisku [72].

\section{PRZYSPIESZONA DEGRADACJA AGREGATÓW $\beta$-AMYLOIDU ORAZ HIPERFOSFORYLOWANEGO BIAŁKA tau POPRZEZ INDUKCJE AUTOFAGII}

Zaproponowana w ostatnim czasie terapia skutkująca degradacją agregatów $\beta$-amyloidu oraz hiperfosforylowanego białka tau oparta jest na zdolnościach genisteiny do indukcji procesu autofagii. Genisteina poprzez aktywację czynnika transkrypcyjnego EB (TFEB) prowadzi do stymulacji biogenezy lizosomów, organelli zaangażowanych w proces autofagii. Ponadto, posiada ona zdolność do aktywacji czynnika FoxO3 poprzez oddziaływanie z receptorem naskórkowego czynnika wzrostowego (EGFR) co również prowadzi do zwiększenia poziomu ekspresji genów kodujących białka zaangażowane w proces autofagii [35,36].

Badania nad szczurzym, streptozotocynowym modelem AD wskazały, że w wysokich dawkach genisteina posiada zdolności do usuwania zarówno krótkich, toksycznych form $\beta$-amyloidu(1-40) oraz (1-42) oraz ich prekursora, białka APP, a także hiperfosforylowanej formy białka tau. Spadkowi poziomów tych białek towarzyszył wzrost liczby lizosomów oraz wzrost poziomów markerów lizosomalnych. Co więcej, badania na modelu komórek HEK-293 z nadekspresją genu kodującego APP wskazały, że zahamowanie funkcji lizosomów znosi ten efekt, co potwierdza, że indukcja autofagii jest kolejnym mechanizmem prowadzącym do ograniczenia ilości płytek amyloidowych w komórkach nerwowych. Badania behawioralne przeprowadzone na tym modelu wskazały na całkowite zniesienie zaburzeń zdolności kognitywnych oraz motorycznych szczurów [73].

Badania te potwierdzają pośrednio wyniki nad syntetycznymi pochodnymi O-alkiloaminowymi genisteiny, które wskazują silne działanie indukujące autofagię oraz obniżające poziomy agregatów $\beta$-amyloidu. Ponadto, charakteryzują się działaniem neuroprotekcyjnym, antyoksydacyjnym oraz przekraczają barierę krew-mózg będąc jednocześnie bezpiecznymi w wysokich dawkach [74].

\section{POTENCJAŁ GENISTEINY W LECZENIU CHOROBY PARKINSONA}

Choroba Parkinsona (PD) jest, zaraz za chorobą Alzheimera, drugim co do częstości diagnozowanym schorzeniem związanym z ubytkami neuronalnymi. Na całym świecie żyje już ponad 10 milionów ludzi zmagających się z tą poważną chorobą, z czego $4 \%$ zostało zdiagnozowanych jeszcze przed ukończeniem 50 roku życia. Badania wskazu- ją, że PD zdecydowanie częściej jest diagnozowana u mężczyzn niż u kobiet, co może wskazywać na rolę estrogenów w ochronie neuronów dopaminergicznych. W badaniach nad zastosowaniem genisteiny do leczenia PD wykorzystywane są różne modele choroby, aby jak najlepiej poznać mechanizmy działania badanego związku [10].

\section{REDUKCJA NEUROTOKSYCZNOŚCI/HAMOWANIE APOPTOZY WYWOŁANEJ POJAWIENIEM \\ SIE AGREGATÓW a-SYNUKLEINY}

Jedno z pierwszych przeprowadzonych badań miało na celu określenie czy genisteina chroni neurony dopaminergiczne przed toksycznym działaniem parakwatu, toksyny wywołującej stres oksydacyjny, a co za tym idzie apoptozę. Doświadczenia przeprowadzone na modelu komórek PC12 wykazały, że wymienione skutki działania toksyny zostały zahamowane po inkubacji w obecności genisteiny [75]. Również cytotoksyczność wywołana 6-hydroksydopaminą (6-OHDA) w tej samej linii komórkowej została zniesiona przez genisteinę, głównie poprzez zahamowanie aktywności kaspazy 3 i 8 [76]. W modelu szczurzym 6-OHDA podane do przyśrodkowej części przodomózgowia prowadzi do obniżenia poziomu neuronów dopaminergicznych i zaburzeń motoryki. Badania wskazały, że przy niskim stężeniu 6-OHDA, leczenie genisteiną pozwoliło na znaczące zachowanie tych funkcji $[77,78]$. Także komórki SH-SY5Y z nadekspresją genu zmutowanej a-synukleiny A53T, poddane działaniu rotenonu (toksyny powodującej wybiórcze uśmiercanie neuronów dopaminergicznych poprzez wzrost poziomu ROS, nadtlenku wodoru i indukcji stresu oksydacyjnego) charakteryzowały się wzrostem żywotności po inkubacji w obecności genisteiny, a zaproponowanym mechanizmem jej działania było zwiększenie poziomu czynników zapobiegających apoptozie [79].

\section{REDUKCJA STRESU OKSYDACYJNEGO I ZAHAMOWANIE STANU ZAPALNEGO WYWOŁANYCH POJAWIENIEM SIĘ AGREGATÓW a-SYNUKLEINY}

Badania na modelu szczurzych komórek neuronowo-glejowych śródmózgowia, w których śmierć zaindukowano przy użyciu lipopolisacharydu (endotoksyny aktywującej mikroglej, uwalniający czynniki prozapalne, m.in. TNF-a, NO i wolne rodniki) wykazały, że genisteina, jej pochodna biochanina A lub daidzeina, skutecznie hamowały aktywację mikrogleju, a co za tym idzie uwalnianie czynników towarzyszących stanom zapalnym, takich jak TNF-a, NO lub wolnych rodników. Prowadziła również do obniżenia poziomu białka chemotaktycznego monocytów-1, interleukiny 6 oraz cytokin $[54,80,81]$.

Badania, wykonane na linii unieśmiertelnionych, dopaminergicznych szczurzych komórkek neuronalnych śródmózgowia poddanych działaniu $\mathrm{H}_{2} \mathrm{O}_{2}$ [powodującemu aktywację kaspazy-3, a w wyniku tego rozpad kinazy białkowej C-delta (PKCdelta)] wykazały, że genisteina drastycznie hamuje rozpad PKCdelta, aktywację kinazy-3, a co za tym idzie apoptozę komórek neuronalnych [82]. Inne doświadczenia wskazały, że uszkodzenie i śmierć neuronów brzusznego rdzenia kręgowego wyizolowanych z kory mózgowej szczurów rasy Sprague-Dawley może być konsekwencją uwalniania cytokin prozapalnych (m. in. TNF-a, IL-1a, IL- 
-1b, IL-1ra, IL-2 i IL-3. IL-1a, IL-2, IL-3) z aktywowanego przez IFN-ץ mikrogleju, przyczyniając się do progresji neurodegeneracji. Ochrona komórek obserwowana po dodaniu genisteiny jest prawdopodobnie związana z zapobieganiem produkcji ROS i zmniejszoną aktywnością czynników proapoptotycznych, a co za tym idzie osłabieniem stresu oksydacyjnego [83].

Badania przeprowadzone na modelu zwierzęcym potwierdziły ochronny wpływ izoflawonów na neurony dopaminergiczne. Prace przeprowadzono na transgenicznych muchach eksprymujących gen ludzkiej a-synukleiny, którym podawano różne stężenia genisteiny. Wyniki tych doświadczeń wskazały na spadek poziomu markerów stresu oksydacyjnego i wzrost zawartości dopaminy, a także wydłużenie życia i opóźnienie utraty zdolności wspinania się u tych zwierząt [84].

\section{MODULACJA POZIOMU NEUROTRANSMITERÓW I TRANSMISJI SYNAPTYCZNEJ W PD}

Również zdolności genisteiny do modulacji poziomu neurotransmiterów zostały wykorzystane w przypadku PD. Z przeprowadzonych badań wynika, że genisteina przywraca niedobór dopaminy i zwiększa ekspresję genu antyapoptotycznego białka Bcl-2 w śródmózgowiu myszy, którym podana została neurotoksyna MPTP (1-metylo-4-fenylo-1,2,3,6-tetrahydropirydyna) znacząco obniżająca poziom dopaminy i jej metabolitów. Stan ten odzwierciedla kobiety w okresie pomenopauzalnym, które są narażone na zachorowanie na PD. Wyniki te wskazują na neuroprotekcyjne działanie genisteiny na mysi model PD indukowany MPTP [85].

\section{POTENCJAŁ GENISTEINY W LECZENIU CHOROBY HUNTINGTONA}

Choroba Huntingtona (HD), genetyczna, postępująca choroba neurodegeneracyjna, dziedziczona w sposób autosomalny dominujaccy, spowodowana jest mutacją skutkującą ekspansją trójek nukleotydów CAG w eksonie 1 genu IT15 (HTT). Mutacja ta prowadzi do powstawania długiego ciągu reszt glutaminy w sekwencji aminokwasowej białka huntingtyny (HTT), co upośledza jego prawidłowe fałdowanie. W rezultacie, zmutowana huntingtyna (mHTT) gromadzi się w komórkach, w tym w neuronach, jako nierozpuszczalne, trudne do usunięcia agregaty, które upośledzają funkcje komórek. Choroba prowadzi do negatywnych skutków psychomotorycznych i kognitywnych. Śmierć następuje zwykle od 15 do 20 lat od diagnozy [10].

Niewiele jest doniesień na temat efektywności działania genisteiny w modelach HD. Te, które pojawiły się w ostatnim czasie zakładają jej aktywności antyoksydacyjne oraz stymulujące degradację mHTT poprzez proces autofagii.

\section{REDUKCJA STRESU OKSYDACYJNEGO ORAZ STANU} ZAPALNEGO I POPRAWA ENERGETYKI KOMÓRKOWEJ

Pierwsze badania nad wykorzystaniem genisteiny w HD przeprowadzane były na szczurzym modelu indukowanym kwasem 3-nitropropionowym (3-NPA). Iniekcja 3-NPA do mózgu prowadzi do zwiększenia poziomu ROS, zaburzeń energetyki komórkowej i indukcji szlaków apoptotycznych.
W konsekwencji u zwierząt występują objawy hipo- i hiper-motoryczne które przypominają niektóre objawy HD. Warto jednak wspomnieć, że w modelu tym nie obserwuje się powstawania agregatów mHTT, zatem odzwierciedla on raczej wtórne zmiany zachodzące w komórkach tj. stres oksydacyjny, zaburzenia funkcji mitochondriów i apoptozę. Szczury z indukowaną poprzez 3-NPA HD leczone genisteiną charakteryzowały się zwiększoną produkcją ATP, zmniejszeniem stresu oksydacyjnego oraz stanu zapalnego, zmniejszonym poziomem acetylocholinoesterazy i zahamowaniem apotozy co prowadziło do poprawy defektów behawioralnych [86,87].

\section{PRZYSPIESZONA DEGRADACJA ZMUTOWANEJ HUNTINGTYNY POPRZEZ INDUKCJĘ AUTOFAGII}

Badania nad rolą autofagii w usuwaniu agregatów mHTT przez genisteinę są jednymi z najnowszych wskazujących na efektywność tej strategii terapeutycznej w przypadku HD. Badania wykonane na modelu komórek HEK293 produkujących mHTT wskazały na dużą efektywność genisteiny $w$ usuwaniu zarówno jej rozpuszczalnej formy jak i tworzonych agregatów, a efektowi temu towarzyszyła indukcja autofagii. Brak funkcjonalności lizosomów, wywołany zastosowaniem chlorochiny, ograniczał ten efekt. Co ciekawe, zjawiska tego nie obserwowano w stosunku do natywnej formy HTT [88]. Badanie te potwierdzone zostały także na modelu fibroblastów pobranych od pacjentów z HD [89].

\section{POTENCJAŁ GENISTEINY W LECZENIU INNYCH CHORÓB NEURODEGENERACYJNYCH}

Rdzeniowo-opuszkowy zanik mięśni (SBMA, Choroba Kennedy'ego) jest rzadką chorobą sprzężoną z chromosomem X, spowodowaną ekspansją trójki nukleotydowej CAG w pierwszym eksonie genu kodującego receptor androgenowy. Częstość występowania SMBA wynosi 1 na 30000 urodzonych chłopców. Pierwsze objawy pojawiają się u chorych mężczyzn między 30 a 60 rokiem życia i zaliczyć do nich można drżenie i skurcze mięśni, niewyraźną mowę oraz zmęczenie. Obecnie nie jest znane leczenie przyczynowe tej choroby. Możliwa jest jedynie rehabilitacja, która daje stosunkowo dobre perspektywy na przyszłość. W 2013 roku przeprowadzono badania z wykorzystaniem linii komórek nerwiaka niedojrzałego (N2a) i linii komórek gruczolakoraka prostaty wskazujące na oddziaływanie receptora androgenowego z ko-regulatorem związanym z AR 70 (ARA70), co zwiększa stabilność tego białka. Genisteina, poprzez zakłócenie interakcji między receptorem androgenowym i ARA70, a co za tym idzie sprzyjaniu degradacji zmutowanego receptora androgenowego, może być potencjalnym lekiem do łagodzenia objawów SBMA [90].

Działanie genisteiny przetestowano również w przypad$\mathrm{ku}$ stwardnienia zanikowego bocznego (ALS) na mysim modelu transgenicznym niosącym mutacje genu SOD1. ALS jest postępującą i śmiertelną chorobą neurodegeneracyjną, atakującą neurony ruchowe kory mózgowej, pnia mózgu oraz rdzenia kręgowego. Początek choroby zwykle występuje około 40-50 roku życia i prowadzi do śmierci 2-5 lat po rozpoznaniu. Pacjenci z ALS cierpią z powodu 
postępującej utraty funkcji układu nerwowo-mięśniowego, takich jak trudności w mówieniu lub przełykaniu oraz porażenie wiotkie lub spastyczne kończyn. Nie ma możliwości leczenia przyczynowego, a stosowana obecnie terapia polega na opóźnieniu wystąpienia niewydolności oddechowej. Badania nad genisteiną wskazały, że jej podawanie indukowało proces autofagii, hamowało produkcję cytokin prozapalnych, zwiększało żywotność neuronów ruchowych oraz łagodziło glejozę u chorych myszy [91,92].

Bardzo obiecujące wyniki przyniosły badania nad wykorzystaniem genisteiny w leczeniu mukopolisacharydoz (MPS), a zwłaszcza typów w których zaatakowany jest ośrodkowy układ nerwowy (MPS I, II, IIIA, IIIB). MPS spowodowane są brakiem aktywności lub szczątkową aktywnością specyficznych enzymów lizosomalnych, co prowadzi do gromadzenia się w lizosomach nierozgałęzionych łańcuchów cukrowych - glikozoaminoglikanów (GAG). Badania przeprowadzone z wykorzystaniem linii komórkowych fibroblastów pobranych od pacjentów, oraz myszy MPS IIIB wskazały, że leczenie genisteiną istotnie zmniejszyło akumulację GAG w komórkach i na modelu mysim oraz stan zapalny w korze mózgowej i hipokampie zwierząt, prowadząc do poprawy zaobserwowanych zaburzeń behawioralnych $[93,94]$ poprzez mechanizm polegający na zależnym od receptora EGF zahamowaniu syntezy GAG [93].

\section{PODSUMOWANIE}

Genisteina jest naturalnie występującym izoflawonem, którego w największych ilościach można znaleźć w roślinach strączkowych. Jej naturalną rolą jest ochrona roślin przed infekcjami i czynnikami środowiskowymi (np. różnego rodzaju promieniowania, ROS, i in.) oraz regulacja wzrostu roślin. Niemniej jednak, różnorodne aktywności biologiczne tego związku (takie jak działanie przeciwutleniające, przeciwzapalne, czy stymulacja autofagii) sprawiają, że jest on brany pod uwagę jako potencjalny lek w wielu chorobach. W szczególności genisteina zwraca uwage jako potencjalny środek do zastosowania $\mathrm{w}$ terapiach chorób neurodegeneracyjnych. Jej właściwości antyoksydacyjne i przeciwzapalne mogą łagodzić objawy uszkodzenia układu nerwowego, natomiast aktywności w modulacji ekspresji genów poprzez oddziaływania z różnymi receptorami i wpływanie na ścieżki przekazywania sygnałów mogą prowadzić do uruchamiania systemów obronnych w komórkach, w tym procesu autofagii, co może mieć szczególne istotne znacznie terapeutyczne. $\mathrm{Z}$ aktywacją autofagii wiąże się duże nadzieje, gdyż około 70\% chorób neurodegeneracyjnych spowodowanych jest odkładaniem się nieprawidłowych makrocząsteczek, które powodują dysfunkcje neuronów. Ich likwidacja w wyniku wzmożonej aktywności systemu lizosomalnego może niwelować pierwotną przyczynę tych chorób, co daje nadzieje na skuteczne ich leczenie. Niemniej jednak, skuteczny lek na te choroby powinien charakteryzować się nie tylko efektywną stymulacją autofagii lecz także przechodzeniem przez barierę krew-mózg oraz bezpieczeństwem w długotrwałym stosowaniu, jako że potencjalne przyjmowanie leku konieczne będzie zapewne do końca życia pacjentów. O ile znanych jest wiele efektywnych stymulatorów autofagii, to genisteina wydaje się związkiem wyjątkowym pod względem spełnienia wszystkich wyżej wymienionych wymagań. Badania przeprowadzone na modelach komórkowych i zwierzęcych rożnych chorób neurodegeneracyjnych, takich jak AD, PD, HD, SBMA, ALS czy neuropatyczne formy MPS, wskazują na efektywności tego izoflawonu zarówno w likwidacji złogów cząsteczek uważanych za podstawowe ich przyczyny, jak też w niwelowaniu objawów. Podsumowanie dotychczasowych badań z użyciem genisteiny jako potencjalnego leku na choroby neurodegeneracyjne, działającego poprzez stymulację procesu autofagii, przedstawia Tabela 1. Przeprowadzenie prób klinicznych powinno odpowiedzieć na pytanie czy związek ten będzie stanowić faktyczny lek na wiele różnych dotychczas nieuleczalnych chorób, zgodnie z niedawno opublikowaną propozycją możliwości użycia jednej substancji do leczenia wielu schorzeń [95].

\section{LITERATURA}

1. Dugger BN, Dickson DW (2017) Pathology of neurodegenerative diseases. Cold Spring Harb Perspect Biol 9(7): a028035

2. Shastry BS (2003) Neurodegenerative disorders of protein aggregation. Neurochem Int 43(1): 1-7

\begin{tabular}{|c|c|c|c|c|}
\hline Choroba & Model & $\begin{array}{l}\text { Badane markery } \\
\text { autofagii }\end{array}$ & Modulacja poziomu patologicznych białek & Literatura \\
\hline \multirow[t]{3}{*}{$\begin{array}{l}\text { choroba } \\
\text { Alzheimera }\end{array}$} & $\begin{array}{l}\text { szczurzy model } \\
\text { indukowany } \\
\text { streptozotocyną }\end{array}$ & $\begin{array}{l}\uparrow \text { liczba lizosomów } \\
\uparrow \text { LC3-II } \\
\uparrow \text { TFEB }\end{array}$ & $\begin{array}{l}\downarrow \beta A(1-40) \\
\downarrow \beta A(1-42) \\
\downarrow \beta A \\
\downarrow \text { APP }\end{array}$ & [73] \\
\hline & $\begin{array}{l}\text { komórki HEK293 } \\
\text { nadeksprymujące } \\
\text { białko APP }\end{array}$ & $\uparrow$ LC3-II & $\begin{array}{l}\downarrow \mathrm{APP} \\
\downarrow \beta \mathrm{A}\end{array}$ & [73] \\
\hline & $\begin{array}{l}\text { komórki U87 transfekowane } \\
\text { stabilnie } \\
\text { GFP-RFP-LC3 }\end{array}$ & $\uparrow$ LC3-II & $\begin{array}{l}\downarrow \text { agregaty } \beta \mathrm{A}(1-40) \text { samoindukowane } \\
\downarrow \text { agregaty } \beta \mathrm{A}(1-40) \text { indukowane przez acetycholinoesterazę } \\
\downarrow \text { agregaty } \beta \mathrm{A}(1-40) \text { indukowane przez Ca2+ }\end{array}$ & {$[74]$} \\
\hline $\begin{array}{l}\text { choroba } \\
\text { Huntingtona }\end{array}$ & $\begin{array}{l}\text { komórki HEK293 } \\
\text { nadeksprymujące } \\
\text { białko HTT/mHTT }\end{array}$ & $\begin{array}{l}\uparrow \text { liczba lizosomów } \\
\uparrow \text { LC3-II }\end{array}$ & $\begin{array}{l}\downarrow \text { mHTT (forma rozpuszczalna) } \\
\downarrow \text { agregaty mHTT }\end{array}$ & {$[88]$} \\
\hline
\end{tabular}

Legenda: $\uparrow$ - wzrost poziomu lub liczby, $\downarrow$ - spadek poziomu lub liczby 
3. Chen WW, Zhang X, Huang WJ (2016) Role of neuroinflammation in neurodegenerative diseases. Mol Med Rep 13(4): 3391-3396

4. Giorgi C, Marchi S, Simoes ICM, Ren Z, Morciano G, Perrone M, Patalas-Krawczyk P, Borchard S, Jędrak P, Pierzynowska K, Szymański J, Wang DQ, Portincasa P, Węgrzyn G, Zischka H, Dobrzyn P, Bonora M, Duszynski J, Rimessi A, Karkucinska-Wieckowska A, Dobrzyn A, Szabadkai G, Zavan B, Oliveira PJ, Sardao VA, Pinton P, Wieckowski MR (2018) Mitochondria and reactive oxygen species in aging and age-related diseases. Int Rev Cell Mol Biol 340: 209-344

5. Lucchinetti C, Brück W, Parisi J, Scheithauer B, Rodriguez M, Lassmann H (2000) Heterogeneity of multiple sclerosis lesions: implications for the pathogenesis of demyelination. Ann Neurol 47(6): 707-717

6. Machaliński B, Łażewski-Banaszak P, Dąbkowska E, Paczkowska E, Gołąb-Janowska M, Nowacki P (2012) Rola czynników neurotroficznych w procesach regeneracji układu nerwowego. Neurologia i Neurochirurgia Polska 46(6): 579-590

7. Tora MS, Texakalidis P, Greven A, Faraj R, Gendreau JL, Liang ZL, Federici T, Boulis NM (2020) Molecular therapeutic strategies in neurodegenerative diseases and injury, W: Salgado AJ (red.) Handbook of Innovations in Central Nervous System Regenerative Medicine. Elsevier, Amsterdam, Holandia, str. 435-486

8. Reyes NA, Fisher JK, Austgen K, Berg SV, Huang EJ, Oakes SA (2010) Blocking the mitochondrial apoptotic pathway preserves motor neuron viability and function in a mouse model of amyotrophic lateral sclerosis. J Clin Invest 120(10): 3673-3679

9. Milewski M, Hoffman-Zacharska D, Bal J (2014) Molekularne strategie terapeutyczne w chorobie Huntingtona. Postepy Biochem 61(1): 18-24

10. Pierzynowska K, Gaffke L, Cyske Z, Puchalski M, Rintz E, Bartkowski M, Osiadły M, Pierzynowski M, Mantej J, Piotrowska E, Węgrzyn G (2018) Autophagy stimulation as a promising approach in treatment of neurodegenerative diseases. Metab Brain Dis 33(4): 989-1008

11. Ricci MS, Zong WX (2006) Chemotherapeutic approaches for targeting cell death pathways. Oncologist 11: 342-357

12. Meijer AJ, Codogno P (2004) Regulation and role of autophagy in mammalian cells. Int J Biochem Cell Biol 36: 2445-2462

13. Liang C, Jung JU (2010) Autophagy genes as tumor suppressors. Curr Opin Cell Biol 22: 226-233

14. Qu X, Zou Z, Sun Q, Luby-Phelps K, Cheng P, Hogan RN, Gilpin C, Levine B (2007) Autophagy gene-dependent clearance of apoptotic cells during embryonic development. Cell 128(5): 931-946

15. Kim R (2005) Recent advances in understanding the cell death pathways activated by anticancer therapy. Cancer 103: 1551-1560

16. Klionsky DJ (2005) The molecular machinery of autophagy: Unanswered questions. J Cell Sci 118: 7-18

17. Cuervo AM (2004) Autophagy: Many paths to the same end. Mol Cell Biochem 263: 55-72

18. Sakai Y, Koller A, Rangell LK, Keller GA, Subramani S (1998) Peroxisome degradation by microautophagy in Pichia pastoris: Identification of specific steps and morphological intermediates. J Cell Biol 141: 625636

19. Mijaljica D, Prescott M, Devenish RJ (2011) Microautophagy in mammalian cells: revisiting a 40-year-old conundrum. Autophagy 7: 673682

20. Kaushik S, Bandyopadhyay U, Sridhar S, Kiffin R, Martinez-Vicente M, Kon M, Orenstein SJ, Wong E, Cuervo AM (2011) Chaperon-mediated autophagy at a glance. J Cell Sci 124: 495-499

21. Dong H, Czaja MJ (2011) Regulation of lipid droplets by autophagy. Trends Endocrinol Metab 22: 234-240

22. Liu XW, Su Y, Zhu H, Cao J, Ding WJ, Zhao YC, He QJ, Yang B (2010) HIF-1a-dependent autophagy protects HeLa cells from fenretinide (4HPR)- induced apoptosis in hypoxia. Pharmacol Res 62: 416-425

23. Zheng Q, Huang T, Zhang L, Zhou Y, Luo H, Xu H, Wang X (2016) Dysregulation of ubiquitin-proteasome system in neurodegenerative diseases. Front Aging Neurosci 8: 303

24. Cuanalo-Contreras K, Moreno-Gonzalez I (2019) Natural products as modulators of the proteostasis machinery: implications in neurodegenerative diseases. Int J Mol Sci 20(19): 4666
25. Krizova L, Dadakova K, Kasparovska, J, Kasparovsky T (2019) Isoflavones. Molecules 24(6): 1076

26. Dixon RA, Ferreira D (2002) Genistein. Phytochemistry 60(3): 205-211

27. Thangavel P, Puga-Olguín A, Rodríguez-Landa J, Zepeda R (2019) Genistein as potential therapeutic candidate for menopausal symptoms and other related diseases. Molecules 24(21): 3892

28. Tang C, Zhang K, Zhao Q, Zhang J (2015) Effects of fietary genistein on plasma and liver lipids, hepatic gene expression, and plasma metabolic profiles of hamsters wit diet-induced hyperlipidemia. J Agric Food Chem 63(36): 7929-7936

29. Fischer N, Seo E, Efferth T (2018) Prevention from radiation demage by natural products. Phytomedicine 47: 192-200

30. Mazumder M., Hongsprabhas P (2016) Genistein as antioxidant and antibrowning agents in in vivo and in vitro: A review. Biomed Pharmacother 82: 379-392

31. Yanhui L, Yu A., Chenyan L, Weiwei M, Yuandi X, Rong X (2018) Dietary soybean isoflavones in Azheimer's disease prevention. Asia Pac J Clin Nutr 27(5): 946

32. Klein CB, King AA (2007) Genistein genotoxicity: critical considerations of in vitro exposure dose. Toxicol Appl Pharmacol 224(1): 1-11

33. Spagnuolo C, Russo GL, Orhan IE, Habtemariam S, Daglia M, Sureda A, Nabavi SF, Devi KP, Loizzo MR, Tundis R, Nabavi SM (2015) Genistein and cancer: current status, challenges, and future directions. Adv Nutr 6(4): 408-419

34. Wang Y, Li Y, Zhang T, Chi Y, Liu M, Liu Y (2018) Genistein and Myd88 activate autophagy in high glucose-induced renal podocytes in vitro. Med Sci Monit 24: 4823-4831

35. Moskot M, Montefusco S, Jakóbkiewicz-Banecka J, Mozolewski P, Węgrzyn A, Di Bernardo D, Węgrzyn G, Medina DL, Ballabio A, Gabig-Cimińska M (2014) The phytoestrogen genistein modulates lysosomal metabolism and transcription factor EB (TFEB) activation. J Biol Chem 289(24): 17054-17069

36. Qi W, Weber CR, Wasland K, Savkovic SD (2011) Genistein inhibits proliferation of colon cancer cells by attenuating a negative effect of epidermal growth factor on tumor suppressor FOXO3 activity. BMC Cancer 11: 219

37. Tsai TH (2005) Concurrent measurement of unbound genistein in the blood, brain and bile of anesthetized rats using microdialysis and its pharmacokinetic application. J Chromatogr A 1073(1-2): 317-322

38. Kim KH, Dodsworth C, Paras A, Burton BK (2013) High dose genistein aglycone therapy is safe in patients with mucopolysaccharidoses involving the central nervous system. Mol Genet Metab 109(4): 382-385

39. Pierzynowska P, Podlacha M, Brokowska J, Gaffke L, Mantej J, Cyske Z, Rintz E, Osiadły M, Bartkowski M, Puchalski M, Grabski M, Pierzynowski M, Pankanin D, Piotrowska E, Tukaj S, Węgrzyn G (2018) Molekularne mechanizmy działania genisteiny w świetle terapii chorób genetycznych i immunologicznych. Postepy Biochem 64(4): 262-276

40. Choi Y, Hong SS, Shin YS, Hwang BY, Park SY, Lee D (2010) Phenolic compounds from Pueraria lobata protect $\mathrm{PC} 12$ cells against $\mathrm{A} \beta$-induced toxicity. Arch Pharm Res 33(10): 1651-1654

41. Luo S, Lan T, Liao W, Zhao M, Yang H (2012) Genistein inhibits $A \beta_{25-35^{-}}$ induced neurotoxicity in PC12 cells via PKC signaling pathway. Neurochem Res 37(12): 2787-2794

42. Zheng Y, You F, Li Q, Chen J, Yang H (2016) The effect of geniste on $\mathrm{A} \beta_{25-35}$-induced PC12 cell apoptosis through the JNK-dependent Fas pathway. Food Funct 7(11): 4702-4708

43. You F, Li Q, Jin G, Zheng Y, Chen J, Yang H (2017) Genistein protects against $\mathrm{A} \beta_{25-35}$ induced apoptosis of PC12 cells through JNK signaling and modulation of Bcl-2 family messengers. BMC Neurosci 18(1): 12

44. Zeng H, Chen Q, Zhao B (2004) Genistein ameliorates beta-amyloid peptide (25-35)-induced hippocampal neuronal apoptosis. Free Radic Biol Med 36(2): 180-188

45. Wang YX, Xia ZH, Jiang X, Li LX, An D, Wang HG, Heng B, Liu YQ (2019) Genistein inhibits $A \beta_{25-35}$-induced neuronal death with changes in the electrophysiological properties of voltage-gated sodium and potassium channels. Cell Mol Neurobiol 39(6): 809-822 
46. Guo J, Yang G, He Y, Xu H, Fan H, An J, Zhang L, Zhang R, Cao G, Hao $\mathrm{D}$, Yang $\mathrm{H}$ (2021) Involvement of $\alpha 7 n A C h R$ in the protective effects of genistein against $\beta$-amyloid-induced oxidative stress in neurons via a PI3K/Akt/Nrf2 pathway-related mechanism. Cell Mol Neurobiol 41(2): 377-393

47. Bang OY, Hong HS, Kim DH, Kim H, Boo YH, Huh K, Mook-Jung I (2004) Neuroprotective effect of genistein against beta amyloid-induced neurotoxicity. Neurobiol Dis 16(1): 21-28

48. Park YJ, Jang Y, Kwon YH (2010) Protective effect of isoflavones against homocysteine-mediated neuronal degeneration in SH-SY5Y cells. Amino Acids 39(3): 785-794

49. Dos Santos Petry F, Paranhos Coelho B, Maier Gaelzer M, Kreutz F, Costa Rodrigues Guma FT, Gazzana Salbego C, Treis Trindade VM (2020) Genistein protects against amyloid-beta-induced toxicity in SHSY5Y cells by regulation of Akt and Tau phosphorylation. Phytother Res 34(4): 796-807

50. Yi S, Chen S, Xiang J, Tan J, Huang K, Zhang H, Wang Y, Wu H (2021) Genistein exerts a cell-protective effect via Nrf2/HO-1/PI3K signaling in $\mathrm{A} \beta_{25-35}$-induced Alzheimer's disease models in vitro. Folia Histochem Cytobiol doi: 10.5603/FHC.a2021.0006

51. Wang Y, Cai B, Shao J, Wang TT, Cai RZ, Ma CJ, Han T, Du J (2016) Genistein suppresses the mitochondrial apoptotic pathway in hippocampal neurons in rats with Alzheimer's disease. Neural Regen Res 11(7): 1153-1158

52. Gutierrez-Zepeda A, Santell R, Wu Z, Brown M, Wu Y, Khan I, Link CD, Zhao B, Luo Y (2005) Soy isoflavone glycitein protects against beta amyloid-induced toxicity and oxidative stress in transgenic Caenorhabditis elegans. BMC Neurosci 6: 54

53. Andersen JM, Myhre O, Fonnum F (2003) Discussion of the role of the extracellular signal-regulated kinase-phospholipase A2 pathway in production of reactive oxygen species in Alzheimer's disease. Neurochem Res 28(2): 319-26

54. Jantaratnotai N, Utaisincharoen $P$, Sanvarinda P, Thampithak A, Sanvarinda Y (2013) Phytoestrogens mediated anti-inflammatory effect through suppression of IRF-1 and pSTAT1 expressions in lipopolysaccharide-activated microglia. Int Immunopharmacol 17(2): 483-488

55. Bagheri M, Joghataei MT, Mohseni S, Roghani M (2011) Genistein ameliorates learning and memory deficits in amyloid $\beta(1-40)$ rat model of Alzheimer's disease. Neurobiol Learn Mem 95(3): 270-6

56. Ma WW, Hou CC, Zhou X, Yu HL, Xi YD, Ding J, Zhao X, Xiao R (2013) Genistein alleviates the mitochondria-targeted DNA damage induced by $\beta$-amyloid peptides $25-35$ in C6 glioma cells. Neurochem Res 38(7): 1315-23

57. Zhou X, Yuan L, Zhao X, Hou C, Ma W, Yu H, Xiao R (2014) Genistein antagonizes inflammatory damage induced by $\beta$-amyloid peptide in microglia through TLR4 and NF-kB. Nutrition 30(1): 90-5

58. Valles SL, Dolz-Gaiton P0, Gambini J, Borras C, Lloret A, Pallardo FV, Viña J (2010) Estradiol or genistein prevent Alzheimer's disease-associated inflammation correlating with an increase PPAR gamma expression in cultured astrocytes. Brain Res 1312: 138-44

59. Bagheri M, Roghani M, Joghataei MT, Mohseni S (2012) Genistein inhibits aggregation of exogenous amyloid-beta ${ }_{1-40}$ and alleviates astrogliosis in the hippocampus of rats. Brain Res 1429: 145-54

60. Orhan I, Kartal M, Tosun F, Sener B (2007) Screening of various phenolic acids and flavonoid derivatives for their anticholinesterase potential. Z Naturforsch C J Biosci 62(11-12): 829-32

61. Wang YX, Xia ZH, Jiang X, Li LX, Wang HG, An D, Liu YQ (2020) Genistein inhibits amyloid peptide 25-35-induced neuronal death by modulating estrogen receptors, choline acetyltransferase and glutamate receptors. Arch Biochem Biophys 693: 108561

62. Xi Y-D, Zhang D-D, Ding J, Yu H-L, Yuan L-H, Ma W-W, Han J, Xiao $\mathrm{R}$ (2016) Genistein inhibits $A \beta_{25-35}$-induced synaptic toxicity and regulates CaMKII/CREB pathway in SH-SY5Y cells. Cell Mol Neurobiol. 36(7): 1151-9

63. Dos Santos Petry F, Bender Hoppe J, Peres Klein C, Dos Santos BG, Hözer RM, Bifi F, Matté C, Gazzana Salbego C, Treis Trindade VM (2021) Genistein attenuates amyloid-beta-induced cognitive impair- ment in rats by modulation of hippocampal synaptotoxicity and hyperphosphorylation of Tau. J Nutr Biochem 87: 108525

64. Li R, He P, Cui J, Staufenbiel M, Harada N, Shen Y (2013) Brain endogenous estrogen levels determine responses to estrogen replacement therapy via regulation of BACE1 and NEP in female Alzheimer's transgenic mice. Mol Neurobiol 47(3): 857-67

65. Youn K, Park JH, Lee S, Lee S, Lee J, Yun EY, Jeong WS, Jun M (2018) BACE1 Inhibition by genistein: biological evaluation, kinetic analysis, and molecular docking simulation. J Med Food 21(4): 416-420

66. Okumura N, Yoshida H, Nishimura Y, Murakami M, Kitagishi Y, Matsuda S (2012) Genistein downregulates presenilin 1 and ubiquilin 1 expression. Mol Med Rep 5(2): 559-61

67. Park YJ, Ko JW, Jeon S, Kwon YH (2016) Protective Effect of Genistein against Neuronal Degeneration in ApoE ${ }^{-1}$ Mice Fed a High-Fat Diet. Nutrients 8(11): 692

68. Kim C, Jang CH, Bang JH, Jung MW, Joo I, Kim SU, Mook-Jung I (2002) Amyloid precursor protein processing is separately regulated by protein kinase $C$ and tyrosine kinase in human astrocytes. Neurosci Lett 324(3): 185-8

69. Shentu YP, Hu WT, Liang JW, Liuyang ZY, Wei H, Qun W, Wang XC, Wang JZ, Westermarck J, Liu R (2019) Genistein decreases APP/tau phosphorylation and ameliorates $\mathrm{A} \beta$ overproduction through inhibiting CIP2A. Curr Alzheimer Res 16(8): 732-740

70. Bonet-Costa V, Herranz-Pérez V, Blanco-Gandía MC, Mas-Bargues C, Inglés M, Garcia-Tarraga P, Rodriguez-Arias M, Miñarro J, Borras C, Garcia-Verdugo JM, Viña J (2016) Clearing amyloid- $\beta$ through PPAR $/$ ApoE activation by genistein is a treatment of experimental Alzheimer's disease. J Alzheimers Dis 51(3): 701-11

71. Ye S, Wang TT, Cai B, Wang Y, Li J, Zhan JX, Shen GM (2017) Genistein protects hippocampal neurons against injury by regulating calcium/ calmodulin dependent protein kinase IV protein levels in Alzheimer's disease model rats. Neural Regen Res 12(9): 1479-1484

72. Liu JYH, Sun MYY, Sommerville N, Ngan MP, Ponomarev ED, Lin G, Rudd JA (2020) Soy flavonoids prevent cognitive deficits induced by intra-gastrointestinal administration of beta-amyloid. Food Chem Toxicol 141: 111396

73. Pierzynowska K, Podlacha M, Gaffke L, Majkutewicz I, Mantej J, Węgrzyn A, Osiadły M, Myślińska D, Węgrzyn G (2019) Autophagy-dependent mechanism of genistein-mediated elimination of behavioral and biochemical defects in the rat model of sporadic Alzheimer's disease. Neuropharmacology 148: 332-346

74. Sang Z, Shi J, Zhou Y, Wang K, Zhao Y, Li Q, Qiao Z, Wu A, Tan Z, Liu W (2021) Development of genistein-O-alkylamines derivatives as multifunctional agents for the treatment of Alzheimer's disease. Bioorg Chem 107: 104602

75. Li X, Sun AY (1999) Paraquat induced activation of transcription factor AP-1 and apoptosis in PC12 cells. J Neural Transm 106 (1): 1-21

76. Lin CM, Lin RD, Chen ST, Lin YP, Chiu WT, Lin JW, Hsu FL, Lee MH (2010) Neurocytoprotective effects of the bioactive constituents of Pueraria thomsonii in 6-hydroxydopamine (6-OHDA)-treated nerve growth factor (NGF)-differentiated PC12 cells. Phytochemistry 71(1718): $2147-56$

77. Kyuhou SI (2008) Preventive effects of genistein on motor dysfunction following 6-hydroxydopamine injection in ovariectomized rats. Neurosci Lett 448(1): 10-4

78. Arbabi E, Hamidi G, Talaei SA, Salami M (2016) Estrogen agonist genistein differentially influences the cognitive and motor disorders in an ovariectomized animal model of Parkinsonism. Iran J Basic Med Sci 19(12): $1285-1290$

79. Wu HC, Hu QL, Zhang SJ, Wang YM, Jin YM, Lv LF, Zhang S, Liu ZL, Wu HL, Cheng OM (2018) Neuroprotective effects of genistein on SHSY5Y cells overexpressing A53T mutant a-synuclein. Neural Regen Res 13(8): 1375-1383

80. Wang X, Chen S, Ma G, Ye M, Lu G (2005) Genistein protects dopaminergic neurons by inhibiting microglial activation. Neuroreport 16(3): 267-70

81. Chen HQ, Jin ZY., Li GH (2007) Biochanin A protects dopaminergic neurons against lipopolysaccharide-induced damage through inhibi- 
tion of microglia activation and proinflammatory factors generation. Neurosci Lett 417(2): 112-7

82. Kaul S, Anantharam V, Yang Y, Choi C, Kanthasamy A, Kanthasamy A (2005) Tyrosine phosphorylation regulates the proteolytic activation of protein kinase Cdelta in dopaminergic neuronal cells. J Biol Chem 280(31): 28721-30

83. McDowell M, Das A, Smith J, Varma A, Ray S, Banik N (2011) Neuroprotective effects of genistein in VSC4.1 motoneurons exposed to activated microglial cytokines. Neurochem Int 59(2): 175-84

84. Siddique YH, Naz F, Jyoti S, Ali F, Rahu (2019) Effect of genistein on the transgenic Drosophila model of Parkinson's disease. J Diet Suppl 16(5): 550-563

85. Liu LX, Chen WF, Xie JX, Wong MS (2008) Neuroprotective effects of genistein on dopaminergic neurons in the mice model of Parkinson's disease. Neurosci Res 60(2): 156-61

86. Menze ET, Esmat A, Tadros MG, Abdel-Naim AB, Khalifa AE (2015) Genistein improves 3-NPA-induced memory impairment in ovariectomized rats: impact of its antioxidant, anti-inflammatory and acetylcholinesterase modulatory properties. PLoS One 10(2): e0117223

87. Menze ET, Esmat A, Tadros MG, Khalifa AE, Abdel-Naim AB (2016) Genistein improves sensorimotor gating: Mechanisms related to its neuroprotective effects on the striatum. Neuropharmacology 105: 3546

88. Pierzynowska K, Gaffke L, Hać A, Mantej J, Niedziałek N, Brokowska J, Węgrzyn G (2018) Correction of Huntington's disease phenotype by genistein-induced autophagy in the cellular model. Neuromolecular Med 20(1): 112-123
89. Pierzynowska K, Gaffke L, Cyske Z, Węgrzyn G (2019) Genistein induces degradation of mutant huntingtin in fibroblasts from Huntington's disease patients. Metab Brain Dis 34(3): 715-720

90. Qiang Q, Adachi H, Huang Z, Jiang YM, Katsuno M, Minamiyama M, Doi H, Matsumoto S, Kondo N, Miyazaki Y, Iida M, Tohnai G, Sobue G (2013) Genistein, a natural product derived from soybeans, ameliorates polyglutamine-mediated motor neuron disease. J Neurochem 126(1): 122-30

91. Trieu VN, Uckun FM (1999) Genistein is neuroprotective in murine models of familial amyotrophic lateral sclerosis and stroke. Biochem Biophys Res Commun 258(3): 685-8

92. Zhao Z, Fu J, Li S, Li Z (2019) Neuroprotective effects of genistein in a SOD1-G93A transgenic mouse model of amyotrophic lateral sclerosis. J Neuroimmune Pharmacol 14(4): 688-696

93. Piotrowska E, Jakóbkiewicz-Banecka J, Barańska S, Tylki-Szymańska A, Czartoryska B, Wegrzyn A, Wegrzyn G (2006) Genistein-mediated inhibition of glycosaminoglycan synthesis as a basis for gene expression-targeted isoflavone therapy for mucopolysaccharidoses. Eur J Hum Genet 14(7): 846-52

94. Malinowska M, Wilkinson FL, Langford-Smith KJ, Langford-Smith A, Brown JR, Crawford BE, Vanier MT, Grynkiewicz G, Wynn RF, Wraith JE, Wegrzyn G, Bigger BW (2010) Genistein improves neuropathology and corrects behaviour in a mouse model of neurodegenerative metabolic disease. PLoS One 5(12): e14192

95. Pierzynowska K, Kamińska T, Węgrzyn G (2020) One drug to treat many diseases: unlocking the economic trap of rare diseases. Metab Brain Dis 35(8): 1237-1240

\title{
Potential of genistein-induced autophagy in the treatment of neurodegenerative diseases
}

\author{
Karolina Pierzynowska ${ }^{\varpi}$, Zuzanna Cyske, Lidia Gaffke, Estera Rintz, Jagoda Mantej, \\ Magdalena Podlacha, Karolina Wiśniewska, Magdalena Żabińska, Maja Sochocka, \\ Patryk Lorenc, Patrycja Bielańska, Izabela Giecewicz, Grzegorz Węgrzyn
}

Department of Molecular Biology, Faculty of Biology, University of Gdansk, Gdańsk

${ }^{\square}$ Corresponding author: karolina.pierzynowska@ug.edu.pl

Key words: genistein, flavonoids, autophagy, neurodegenerative disease, therapeutic strategies

\begin{abstract}
Development of therapies for neurodegenerative diseases, disorders characterized by progressing loss of neurons, is a great challenge for current medicine. Searching for drugs for these diseases is being proceeded in many laboratories in the world. To date, several therapeutical strategies have been proposed which, however, are either of insufficient efficacy or at the early preclinical stages. One of the newest concepts is elevated efficiency of degradation of protein aggregates which are causes of $70 \%$ of these diseases. Autophagy, i.e. lysosomal degradation of macromolecules, is a process which could be employed in such a strategy Searching for a compound which would not only stimulate autophagy but also reveal safety in a long-term usage and be able to cross the blood-brain-barrier led to studies on one of flavonoids, genistein which occurs at high concentrations in soy. Experiments with this compound indicated its enormous efficiency in removing protein aggregated formed by beta-amyloid, hyperphosphorylated tau protein, and mutant huntingtin. Moreover, using animal models of these diseases, correction of cognitive and motoric symptoms was demonstrated. Considering safety of genistein as well as its ability to crossing the blood-brain-barrier, one may assume that this molecule is a candidate for an effective drug in therapies of not only Alzheimer disease and Huntington disease, but also other disorders caused be protein aggregates. In this article, recent results of studies on the use of genistein in different models of neurodegenerative diseases are summarized, with special emphasis on its autophagy-dependent action.
\end{abstract}




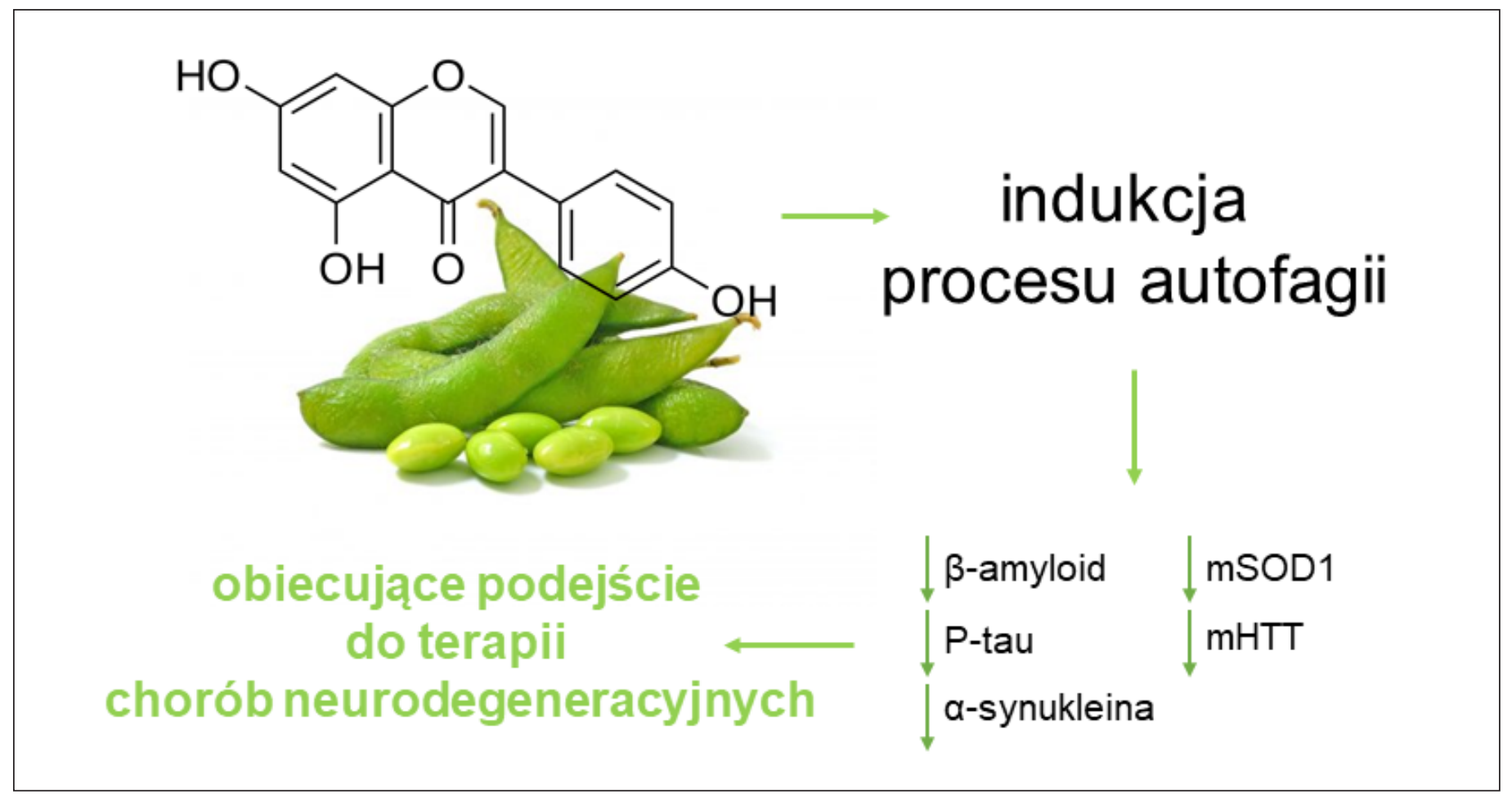

